Костур К.П. ${ }^{1}$, Фальбуш O.O. ${ }^{1}$, Корчинська O.O. ${ }^{2}$

\title{
Роль офтальмолога в обстеженні вагітних жінок: аналітичний огляд наукової літератури
}

\author{
ДВНЗ «Ужгородський національний університет», м. Ужгород, Україна: \\ 1Факультет післядипломної освіти та доуніверситетської підготовки, кафедра хірургічних дисциплін \\ ${ }^{2}$ Медичний факультет, кафедра акушерства та гінекології
}

\begin{abstract}
Мета дослідження: розглянути клінічні особливості обстеження офтальмологічного статусу вагітних, виявити найбільш поширені офтальмологічні захворювання та ускладнення, які пов'язані з вагітністю та пологами, визначити тактику ведення вагітності і пологів .

Об’єкт і методи дослідження: дані наукової медичної літератури вітчизняних та зарубіжних авторів з медичної бібліотеки Закарпатського обласного медичного інформаційно-аналітичного центру, інформачія з джерел Інтернету. Результати. Серед числа екстрагенітальних патологій проблеми органа зору зустрічаються часто. 3 урахуванням особливостей офтальмологічного огляду вагітних, виділяються 3 групи пацієнтів: I група - фізіологічна вагітність без патології органа зору; II - фізіологічна вагітність з патологією органа зору в анамнезі; III - патологічно перебігаюча вагітність з патологією органа зору, яка виникла внаслідок ускладнення вагітності. Важливим аспектом є виявлення дистрофічних змін не пізніше 34-го тижня вагітності для збереження можливості проведення лазеркоагуляції сітківки. Висновки. Офтальмологічне обстеження вагітних має ряд особливостей. Необхідно диференціювати фізіологічні прояви вагітності від патологічних. Але навіть коли лікар-офтальмолог дає рекомендації щзодо способу розродження жінки, рішення про ведення пологів в кожній ситуачії остаточно ухвалює лікар-акушер-гінеколог.

Ключові слова: офтальмологічний статус, захворювання очей, вагітність, екстрагенітальні ускладнення, міопія, вітреохоріоретинальна дистрофія, прееклампсія.
\end{abstract}

№ державної реєстрації НДР $0115 \mathrm{U} 001289$

\section{Вступ}

$\mathrm{B}$ агітні жінки належать до категорії найбільш обстежених пацієнтів. При цьому важливим $\epsilon$ виявлення у вагітних екстрагенітальної патології, характер якої може змінитись в зв'язку зі змінами гормонального фону при появі нової, але тимчасової, залози внутрішньої секреції - плаценти [1].

За даними літератури, приблизно у 49\% жінок репродуктивного віку зустрічається та чи інша патологія органу зору [2]. Тому при обстеженні вагітних особлива роль надається лікарю-офтальмологу. Офтальмологічні захворювання i вагітність взаємопов'язують перебіг i результат один одного.

Вагітна з обтяженим офтальмологічним анамнезом потребує особливого підходу з боку акушер-гінеколога. Інтерес до стану очей обумовлений не лише тим, що виявлені офтальмологом захворювання можуть вимагати зміни тактики ведення вагітності і пологів, але і тим, що деякі очні симптоми допоможуть в постановці терапевтичного, акушерського діагнозу i визначенні динаміки хвороби.

До основних задач лікаря-офтальмолога, який консультує вагітних, відносять: діагностику первинної патології органа зору, особливо тієї, яка може мати негативний прогноз в плані збереження зору при самостійному розродженні, оцінку стану очного дна i виявлення ознак гестозу [3]. При цьому необхідна як рання діагностика гестозу (можлива у 17-40\% вагітних), так i оцінка проявів пізнього гестозу, що важливо при прогнозуванні групи ризику судинних розладів у віддаленому післяпологовому періоді.

Мета дослідження: розглянути клінічні особливості обстеження офтальмологічного статусу вагітних, виявити найбільш поширені офтальмологічні захворювання та ускладнення, які пов'язані з вагітністю та пологами, визначити тактику ведення вагітності і пологів .

Об'єкт і методи дослідження: авторами проаналізовані дані наукової медичної літератури вітчизняних та зарубіжних авторів у медичній бібліотеці Закарпатського обласного медичного інформаційноаналітичного центру та інформація 3 джерел Інтернету. Всього проаналізовано 21 наукове інформаційне джерело.

\section{Результати дослідження та їх обговорення}

Офтальмологічний огляд вагітних має багато особливостей. До них належать етапи і форми огляду 3 врахуванням терміну вагітності, а також клінічні особливості, що дозволяють правильно диференціювати фізіологічні прояви нормальної вагітності від патологічних станів [2].

3 урахуванням особливостей офтальмологічного огляду вагітних, виділяються такі групи пацієнтів:

І група - фізіологічна вагітність без патології органа зору; 
II група - фізіологічна вагітність з патологією органа зору в анамнезі, такою як міопія, периферична вітреохоріоретинальна дистрофія (ПВХРД), відшарування сітківки, скловидного тіла, судинної оболонки та інше;

III група - патологічно перебігаюча вагітність 3 патологією органа зору, яка виникла внаслідок ускладнення вагітності, такого як прееклампсія, анемія, гестаційний цукровий діабет тощо.

I група. Головним завданням лікаря-офтальмолога в цій клінічній групі $\epsilon$ необхідність виключити офтальмопатологію та дати заключення щодо пологів. Під час вагітності жінка повинна пройти два обов'язкові консультативні огляди у офтальмолога: 1-ий - на ранніх термінах вагітності, при реєстрації на облік у жіночу консультацію - на 12-14 тижні; 2-ий - на третьому триместрі вагітності - на 30-32 тижні. Третій огляд показаний не всім вагітним, а тим, у кого є патологічний перебіг вагітності [2].

Огляд повинен проводитися в умовах максимального медикаментозного мідріазу, що дозволяє візуалізувати периферичні відділи очного дна і виключити наявність дистрофічних змін. Найбільш пізній термін офтальмологічного огляду вагітної у стані медикаментозного мідріазу - 34-й тиждень вагітності. Це пов'язано 3 тим, що у випадках виявлення патології на очному дні, яка потребує лазерної коагуляції сітківки, необхідний достатній термін до настання пологів для формування рубців на сітківці, що попереджують іiі відшарування.

Гормональні, метаболічні, гемодинамічні, судинні і імунологічні зміни, що відбуваються під час вагітності, можуть впливати на стан органа зору. Вплив вагітності на очі може провокувати фізіологічні чи патологічні зміни, що можуть привести до розвитку очної патології або підсилити прояви уже існуючої [2, 4]. До найбільш поширених фізіологічних змін відносяться: підвищена пігментація навколо очей, птоз, зменшення кон'юнктивальних капілярів, зміна чутливості і товщини рогівки, зниження толерантності до контактних лінз, гемералопія, пігментація задньої поверхні рогівки $[5,6]$. Близько у $10 \%$ вагітних зустрічаються субкон'юнктивальні крововиливи під час вагітності чи після пологів. Дані зміни можна віднести до фізіологічних і таких, що не потребують медикаментозного втручання. Однак у разі виникнення субкон'юнктивальних крововиливів, потрібно здійснювати контроль артеріального тиску [7]. Деякі жінки під час вагітності відмічають сухість очей і світлобоязнь. Це пов'язано зі зниженням функціональної активності слізних залоз внаслідок гормональної перебудови організму. Зниження функціональної активності слізних залоз підтверджується біомікроскопією рогівки, фарбованою $0,1-0,2 \%$ розчином флюоресцеїну натрію (проба Норна), тестом Ширмера. Даний симптом зникає після пологів [8]. Часто, особливо в 3-му триместрі, вагітні скаржаться на зниження зору. Дані зміни зустрічаються приблизно у 14\% вагітних і можуть виникати внаслідок декількох факторів: зміна кривизни кришталика, зниження чутливості рогівки, збільшення товщини рогівки внаслідок набряку [2, 9].
Враховуючи цей факт, рефракційні хірургічні втручання не повинні проводитися під час вагітності і протягом першого року після пологів [10].

Скарги на зниження зору під час вагітності можуть бути обумовлені розвитком центральної серозної хоріоретинопатії. Центральна серозна хоріоретинопатія характеризується накопиченням субретинальної рідини, що викликає нейросенсорне відшарування сітківки в ділянці макули. Підвищений рівень ендогенного кортизолу провокує підвищення проникності в хоріокапілярному руслі, що викликає відшарування нейроепітелію i супроводжується виникненням односторонніх метаморфопсій та вираженим зниженням гостроти зору. Це захворювання частіше зустрічається у чоловіків, проте у жінок частота виникнення корелює 3 вагітністю, особливо на пізніх термінах. Центральна серозна хоріоретинопатія $\epsilon$ рідким ускладненням вагітності, яке зазвичай спонтанно зникає після пологів, 3 мінімальними наслідками чи без них [6].

II група. До цієї групи належать пацієнти з різними видами офтальмопатології в анамнезі: міопією, периферичною хоріоретинальною дистрофією, відшаруванням сітківки тощо [2].

Особлива увага лікарів-офтальмологів надається вагітним 3 міопічною рефракцією. За даними літератури, питання міопії у вагітних найбільш широко досліджено і вивчено. В структурі екстрагенітальної патології у вагітних міопія складає 18-20\% [2, 8]. Проблема міопії актуальна у зв'язку з тим, що наявність високих ступенів міопії веде за собою питання щодо тактики розродження. Одним з найбільш небезпечних ускладнень зі сторони органа зору у вагітних $є$ відшарування сітківки. Найчастішою причиною цього $\epsilon$ периферична вітреохоріоретинальна дистрофія (ПВХРД). Ступінь міопії не пов'язаний з ризиком і тяжкістю ПВХРД і тому лише на його основі не можна оцінювати ризик виникнення ускладнень під час пологів [11]. Вибір методу розродження повинен грунтуватися на оцінці дистрофічних змін в сітківці, що становлять небезпеку розвитку ускладнень, а також на наявності/відсутності дистрофічного відшарування. Самостійні пологи через природні шляхи можливі навіть після операції, виконаної 3 приводу відшарування сітківки, при умові повного анатомічного прилягання сітківки і коагуляції розривів до 35-37 тижня гестації, а також після перенесеної операції 3 приводу відшарування сітківки, проведеної до вагітності і при нормальному стані сітківки в момент огляду [12]. Деякі автори стверджують, що не ступінь міопічної рефракції, а наявність потенційно небезпечних форм ПВХРД визначає ризик виникнення регматогенного відшарування сітківки під час вагітності і пологів [3].

Більшість авторів вважають, що можна виділити абсолютні і відносні покази до проведення кесаревого розтину з боку патології органа зору [2, 3, 8]. До абсолютних показань відносять: відшарування сітківки під час пологів; відшарування сітківки, яке діагностовано i проопероване на 30-40 тижні вагітності; раніше опероване відшарування сітківки на єдиному зрячому оці. До відносних показань для проведення кесаревого розтину 
можна віднести: наявність великих зон периферичної вітреохоріоретинальної дистрофії 3 вітреоретинальними тракціями; відшарування сітківки в анамнезі [2]. Згідно 3 наказом МО3 України від 27.12.2011 р. №977 «Клінічний протокол акушерської допомоги «кесарів розтин» показанням до планової операції кесаревого розтину у жінок 3 офтальмологічною патологією $є$ такі стани: геморагічна форма ретинопатії, перфоративна виразка рогівки, поранення очного яблука 3 проникненням, «свіжий» опік. Інша, крім вищеперерахованих, патологія органа зору не є показанням до кесаревого розтину [13].

Своєчасно проведена лазерна коагуляція сітківки дозволяє звести до мінімуму небезпеку виникнення відшарування сітківки. Тому, при виявленні ПВХРД у вагітних, після згоди пацієнтки, потрібно провести профілактичну лазеркоагуляцію сітківки [2, 14]. Для блокування зон дистрофії раціонально вибрати максимально щадні режими коагуляції. При необхідності лікування проводиться в декілька етапів. Результати оцінюють через 2-3 тижні після останнього сеансу. Якщо всі зони дистрофії блоковані, контрольний огляд рекомендовано провести на 35-37 тижні вагітності. При відсутності ознак прогресування дистрофічного процесу, офтальмолог дає висновок про можливість самостійних пологів через природні пологові шляхи. В рідкісних випадках можливе прогресування ПВХРД, навіть попри виконану раніше лазерну коагуляцію сітківки. В таких ситуаціях варто провести оперативне розродження для попередження серйозних ускладнень з боку органа зору [3].

Особливу увагу варто приділити вагітним з іншими, раніше діагностованими, захворюваннями, такими як хвороба Грейвса, пігментний ретиніт, діабетична ретинопатія, глаукома. В деяких випадках може спостерігатися прогресування діабетичної ретинопатії i центральної серозної хоріоретинопатії 3 підвищеним ризиком відшарування сітківки [2].

Прогресування діабетичної ретинопатії спостерігається у 9,7\% вагітних. Погіршення перебігу ретинопатії під час вагітності обумовлено самою вагітністю, а також рядом інших факторів: змінами ретинального кровотоку, тривалістю діабету, тяжкістю ретинопатії до вагітності, наявністю гіпертензії, діабетичної нефропатії, недостатнім глікемічним контролем і темпами нормалізації глікемії [15].

Для профілактики маніфестації і прогресування ретинопатії під час вагітності, що протікає на фоні цукрового діабету, найбільше значення має преконцептуальна нормалізація глікемії 3 концентрацією глікозильованого гемоглобіну (HbAlc) нижче 6,1\% i зниження до нормальних показників рівня артеріального тиску [16].

Важливий моніторинг стану очного дна протягом вагітності - не менше двох разів в різних триместрах, а також в післяпологовому періоді до повної стабілізації процесу. Своєчасне виявлення ознак прогресування діабетичної ретинопатії під час вагітності дозволяє стабілізувати перебіг захворювання і сприяє збереженню зорових функцій [16]. Прогресування діабетичної ретинопатії можливе і в післяпологовому періоді, в зв’язку
3 чим потрібне спостереження пацієнток з ретинопатією після пологів [16].

Звертає на себе увагу ряд досліджень, які зазначають, що стан при глаукомі i неінфекційних увеальних запальних процесах може тимчасово покращуватися під час вагітності [14]. При спостереженні за вагітною жінкою, хворою на глаукому, необхідно враховувати можливий побічний вплив ліків як на організм вагітної, так і плоду [8].

III група. До цієї групи належать пацієнти, у яких на фоні ускладнень вагітності, таких як прееклампсія, еклампсія, анемія вагітних, гестаційний цукровий діабет, виникають патологічні зміни органа зору [2].

Як і при фізіологічній вагітності, так і при іiі ускладненнях, поряд 3 перерозподілом центрального i мозкового кровообігу відбуваються суттєві зміни гемодинаміки очей [17]. Ці зміни обумовлені спазмом артеріол, який приводить до підвищеної резистентності периферичних судин і системної гіпертонії. Вагітність сама по собі є значним гемодинамічним і метаболічним навантаженням на організм матері i пов'язана 3 необхідністю забезпечення достатнього рівня гемодинаміки і вмісту кисню для плоду за рахунок перерозподілу циркулюючої крові на максимальне забезпечення плацентарного кровообігу. При цьому периферична гемодинаміка, в тому числі і органа зору, знижується [18, 19]. Розрізняють функціональні зміни кровотоку без офтальмологічних порушень сітківки і органічні - 3 видимими порушеннями на очному дні. До функціональних змін відносять зміни калібру і характеру ходу ретинальних судин (ангіопатія сітківки), до органічних - гостру непрохідність судин, крововиливи в сітківку, набряк і відшарування сітківки [2].

В першу чергу, ці зміни характерні для прееклампсії. При нормально перебігаючій вагітності фізіологічне розширення судин i їх низький опір току крові залежить від вироблення біологічно рівноцінних об'ємів вазодилятатора простацикліна та вазоконстриктора тромбоксана. При прееклампсії в утворенні цих двох ейкозаноїдів переважає тромбоксан, що спричиняє спазм судин та системну гіпертонію [18]. На даний час, внаслідок високої концентрації ендотелій-продукуючих факторів, прееклампсія розглядається як дифузна ендотеліопатія, тобто має місце синдром ендотеліальної дисфункції. Саме подібний стан може бути одним із пускових факторів для розвитку очної патології (глаукома, ішемічний синдром, ретинальні тромбози, вікова макулярна дегенерація) [20, 21]. При вагітності, що перебігає з різними ступенями прееклампсії, погіршення функціонального стану очей на фоні гемоциркуляторних змін буває більш вираженим, ніж при неускладненому перебігу вагітності. Наявність скотом, диплопія, зниження гостроти зору, фотопсії, спостерігаються у 25\% жінок 3 прееклампсією і у 50\% - з еклампсією. В тяжких випадках може виникнути кортикальна сліпота, що уражає до $15 \%$ жінок із прееклампсією та еклампсією. Їй передують чи супроводжують головний біль, гіперрефлексія і парез. Дані зміни при відсутності супутньої патології регресують протягом тижня, хоча двосторонні скотоми і дефекти 
полів зору можуть зберігатися впродовж декількох місяців після пологів [8].

Офтальмологічний огляд показаний при виражених порушеннях гемодинаміки у вагітних $з$ анемією. У даної групи пацієнток дефіцит кровотоку складає 35-40\%. При офтальмоскопії виявляють виражене звуження судин сітківки, мікроаневризми, крововиливи у вигляді мазків [2].

\section{Висновки}

Офтальмологічне обстеження вагітних має ряд особливостей. Вагітні, які мають морфофункціональні порушення з боку органа зору, потребують особливої уваги i обстеження. Необхідно диференціювати фізіологічні прояви вагітності, від патологічних. Важливим аспектом є виявлення відшарування сітківки, дистрофічних змін не пізніше 34-го тижня вагітності для збереження можливості проведення лазеркоагуляції сітківки. Але навіть коли лікар-офтальмолог дає рекомендації щодо способу розродження жінки, рішення про ведення пологів в кожній конкретній ситуації остаточно ухвалює лікар-акушер-гінеколог.

\section{Перспективи подальших досліджень}

Серед числа екстрагенітальної патології проблеми органа зору зустрічаються часто. Тому обстеження вагітних у лікаря-офтальмолога має залишатися обов'язковим i здійснюватися за спеціальним алгоритмом. Поки що достатньо не вивчені особливості морфофункціональних змін очного дна при ускладненнях, які виникають під час вагітності. Також, проблема вибору оптимального співвідношення між ризиком втрати зору при фізіологічних пологах і можливим розвитком інтра- чи післяопераційних ускладнень внаслідок кесаревого розтину залишається надзвичайно актуальною на сьогоднішній час.

\section{Література}

1. Коленко О.В., Сорокин Е.Л., Егоров В.В. Состояние области макулы у женщин при преэклампсии и после родов // Офтальмологический журнал. - 2015. - №3. - С. 47-53.

Kolenko O.V., Sorokin E.L., Egorov V.V. Sostojanie oblasti makuly u zhenshhin pri prejeklampsii i posle rodov. [Condition of macular retina in women at preeclampsia and after the delivery]. Oftalmologicheskii jurnal. 2015;3:47-53 (In Russian).

2. Трубилин В.Н., Полунина Е.Г., Анджелова Д.В., Казарян Е.Е., Евстигнеева Ю.В. Клинические особенности офтальмологического статуса беременных // Новости медицини и фармации. - 2018. - № 669. - С. 55-60.

Trubilin V.N., Polunina E.G., Andzhelova D.V., Kazarjan Ye.Ye., Yevstigneyeva Ju.V. Klinicheskie osobennosti oftal'mologicheskogo statusa beremennyh [Clinical Features of the Ophthalmic Status in Pregnant Women]. Novosti medicini i farmacii.2018;669:55-60 (in Russian).

3. Краснощекова E.E., Бойко Э.В., Шадричев Ф.Е. Эволюция взглядов на выбор метода родоразрешения в зависимости от состояния глазного дна у беременных с периферической витреохориоретинальной дистрофией и регматогенной отслойкой сетчатки // Офтальмологические ведомости. - 2011. - Т. 4, № 2. - С. 62-68.

Krasnoshchekova E.E., Boiko E.V., Shadrichev F.E. Evoliutsiia vzgliadov na vybor metoda rodorazresheniia $\mathrm{v}$ zavisimosti ot sostoianiia glaznogo dna u beremennykh s perifericheskimi vitreokhorioretinal'nymi distrofiiami i regmatogennoi otsloikoi setchatki [Evolution of views on the choice of the method of delivery depending on the state of the fundus in pregnant women with peripheral vitreochorioretinal dystrophy and rheumatogenic retinal detachment]. Oftal'mol. vedomosti. 2011; 4 (2): 62-8. (in Russian).

4. Omoti A.E., Waziri-Erameh J.M., Okeigbemen V.W. A review of the changes in ophthalmic and visual system in pregnancy. Afr. J. Reprod. Health. 2018; 12 (3): 185-196.

5. Gotovac M., Kastelan S., Lucenda A. Eye and pregnancy. Coll. Antropol. 2013; 37 (1): 189-193.

6. Maggio E., Polito A., Freno M.C., Pertile G. Multimodal imaging finding in a case of severe Central Serous Chorioretinopathy in an uncomplicated pregnancy. BMC Ophthalmol. 2015; 15: 183.

7. Mackensen F., Paulus W.E., Max R., Ness T. Ocular Changes During Pregnancy. Dtsh. Arztebl. Int. $2014 ; 111$ (33-34): 567-576.

8. Синчихин С.П., Рамазанова Л.Ш., Мамиев О.Б. и др. Беременность и заболевания глаз (обзор литературы). Гинекология. 2016; 1 (6): 43-50.

Sinchihin S.P., Ramazanova L.Sh., Mamiev O.B. i dr. Beremennost' i zabolevanija glaz (obzor literatury) [Pregnancy and eye diseases (literature review)]. Ginekologija. 2016;1(6):43-50. (in Russian).

9. Sharma S., Wuntakal R., Anand A. Sharma T., Downey G. Pregnancy and the eye. The Obstetrician \& Gynecologist. 2006; 8: 141-146.

10. Sharma S., Sharma T., Downey G. Refractive issues in pregnancy. Aust. N.Z. J. Obstet. Gynaecol. 2006;46:186-188.

11. Рочева С.Л. Выбор метода родоразрешения у женщин с миопией различной степени // Вестник офтальмологи. - 2006. - № 3. - С. 47-51.

Rocheva S.L. Vybor metoda rodorazresheniia u zhenshchin s miopiei razlichnoi stepeni. Vestn. oftal'mol. 2006; 3: 47-51. (in Russian). 
12. Коленко О.В., Сорокин Е.Л. Родоразрешение при миопии у беременных женщин, выбор тактики. 2016 ; (3): 64-68.

Kolenko O.V., Sorokin E.L. Rodorazreshenie pri miopii u beremennyh zhenshhin, vybor taktiki. [Delivery in pregnant women with myopia, the choice of tactics]. Oftal'mokhirurgiya. 2016;(3):64-68. (in Russian).

13. Бондаренко O.В. Актуальні питання ведення вагітності та пологів у жінок з міопією високого ступеня. Огляд медичної літератури // Слово о здоровье. - 2017. - № 3 (9). - С. 46-49.

Bondarenko O.V. Aktualni pytannia vedennia vahitnosti ta polohiv u zhinok z miopiieiu vysokoho stupenia. Ohliad medychnoi literatury [Topical issues of pregnancy and childbirth in women with high myopia. Review of medical literature]. Slovo o zdorov'e. 2017;3(9):46-9. (in Ukrainian).

14. Рочева С.Л. Спорные аспекты тактики ведения беременности и родов у женщин с миопией // Актуальные проблемы офтальмологии: матер. Всерос. науч. конф. молодых ученых: сб. науч. тр. / под. ред. Х.П. Тахчиди. M., 2006. - C. 309-311.

Rocheva S.L. Spornye aspekty taktiki vedeniia beremennosti i rodov u zhenshchin s miopiei [Controversial aspects of pregnancy and childbirth tactics in women with myopia]. Aktual'nye problemy oftal'mologii. Mater. Vseros. nauch. konf. molodykh uchenykh. Sb. nauch. tr. M., 2006; 309-11. (in Russian).

15. Egan A.M., VcVicker L., Heerey A., Carmody L., Harney F., Dunne F.P. Diabetic retinopathy in pregnancy: a population-based study of women with pregestational diabetes. Journal of Diabetes Research. 2015; 2015:1-7.

16. Помыткина Н.В. Диабетическая ретинопатия и беременность // Офтальмология. - 2018. - №15. - С. $268-272$.

Pomytkina N.V. Diabeticheskaja retinopatija i beremennost' [Diabetic Retinopathy and Pregnancy] Oftal'mologija. 2018; 15:268-272. (in Russian).

17. Краснощекова E.E., Панкрушова Т.Г., Бойко Э.В. Периферические витреохореоретинальные дистрофии и отслойка сетчатки у беременных: диагностика, лечение, выбор метода родоразрешения. Вестн. офтальмолог. - 2009. № 2. - C. 40-43.

Krasnoshchekova E.E., Pankrushova T.G., Boiko E.V. Perifericheskie vitreokhorioretinal'nye distrofii i otsloika setchatki u beremennykh: diagnostika, lechenie, vybor metoda rodorazresheniia [Peripheral vitreoreoretinal dystrophies and retinal detachment in pregnant women: diagnosis, treatment, choice of delivery method]. Vestn. oftal'molog. 2009; 2: 40-3. (in Russian)

18. Братко Г.В., Трунов А.Н., Черных В.В. Поздний гестоз беременности и функциональное состояние органа зрения (обзор литературы). Сибирский медицинский журнал. - 2010. - Том 25, № 4, Випуск 2. - С. $15-18$.

Bratko G.V., Trunov A.N., Chernyh V.V. Pozdnij gestoz beremennosti i funkcional'noe sostojanie organa zrenija (obzor literatury) [Gestosis of late pregnancy and functional state of the organ of vision]. Sibirskij medicinskij zhurnal. 2010; 25(4): 15-8. (in Russian).

19. Коленко О.В., Сорокин Е.Л. Изучение возможной причинной связи между формированием острой сосудистой патологии глаза у женщин и перенесенням ОПГ-гестозом // Бюллетень Сибирского отделения Российской академии медицинских наук. - 2009. - №4. - С. 85-88.

Kolenko O.V., Sorokin E.L. Izuchenie vozmozhnoj prichinnoj svjazi mezhdu formirovaniem ostroj sosudistoj patologii glaza $\mathrm{u}$ zhenshhin i perenesennjam OPG-gestozom [Studying of the possible causal relationship between formation of the sharp vascular pathology of the eye at women and transferred OPH-gestosis]. Bulletin of the Siberian Branch of the Russian Academy of Medical Sciences=Bulleten Sibirskogo otdeleniya Rossiiskoi akademii meditsinskikh nauk. 2009;29(4):85-88. (In Russian).

20. Коленко О.В., Помыткина Н.В., Сорокин Е.Л., Пашенцев Я.Е. Морфометрические исследования макулы при беременности, осложненной преэклампсией // Практическая медицина. - 2018. - № 3 (114). - С. 97-100.

Kolenko O.V., Pomytkina N.V., Sorokin E.L., Pashencev Ja.E. Morfometricheskie issledovanija makuly pri beremennosti, oslozhnennoj prejeklampsiej [Morphometric studies of the macula in pregnancy complicated by preeclampsia]. Prakticheskaja medicina. 2018;3(114): 97-100. (in Russian).

21. Макулова O.B. Эндотелиальная дисфункция в патогенезе гестоза // Журнал акушерства и женских болезней. - 2014. - Т. 63, № 6. - С. 44-54.

Makulova O.V. Endotelial'naja disfunkcija v patogeneze gestoza [Endothelial dysfunction in the pathogenesis of gestosis]. Zhurnal akusherstva i zhenskih boleznej. 2014;63(6):44-54. (in Russian).

Дата надходження рукопису до редакиї: 23.09.2019 p. 
Роль офтальмолога в обследовании беременных женщин: аналитический обзор научной литературы

Костур К.П. ${ }^{1}$, Фальбуши О.O. ${ }^{1}$, Корчинская O.O. ${ }^{2}$ ГВУЗ «Ужгородський национальный университет»: ${ }^{1}$ Факультет последипломного образования и доуниверситетской подготовки, кафедра хирургических дисциплин

${ }^{2}$ Медицинский факультет, кафедра акушерства и гинекологии

Цель работы: рассмотреть клинические особенности офтальмологического статуса беременных, выявить наиболее распространены офтальмологические заболевания и усложнения, связаны с беременностью, определить тактику ведения беременности и родов.

Материалы и методы: было проанализировано данные научной медицинской литературы в медицинской библиотеке Закарпатского областного медицинского информационно-аналитического центра, собрано информацию с источников Интернета.

Результаты. Среди числа экстрагенитальных патологий проблемы органа зрения встречаются достаточно часто. $\mathrm{C}$ учетом особенностей офтальмологического осмотра беременных, выделяются 3 группы пациентов: I группа - физиологическая беременность без патологии органа зрения; II группа физиологическая беременность с патологией органа зрения в анамнезе III группы - патологически текущая беременность с патологией органа зрения, возникшая в результате осложнения беременности. Важным аспектом является выявление дистрофических изменений не позднее 34-й недели беременности для сохранения возможности проведения лазеркоагуляции сетчатки.

Выводы. Офтальмологическое обследование беременных имеет ряд особенностей. Нужно дифференцировать физиологические проявления беременности от патологических. Но даже когда врач-офтальмолог дает заключения по поводу способа родоразрешения женщины, решения о ведении родов в каждой ситуации окончательно принимает врач-акушер-гинеколог.

Ключевые слова: офтальмологический статус, заболевания глаз, беременность, экстрагенитальные усложнения, миопия, витреохориоретинальная дистрофия, преэклампсия.

The role of an ophthalmologist

in the examination of pregnant women: analytical review of scientific literature

Kostur K.P. ${ }^{1}$, Falbush O.O. ${ }^{1}$, Korchynska O.O. ${ }^{2}$ Uzhhorod National University:

${ }^{1}$ Faculty of postgraduate and pre-university education, Department of surgical disciplines

${ }^{2}$ Medical faculty, Department of obstetrics and gynecology

Aim: consider the clinical features of the examination of the ophthalmologic status pregnant women, identify the most common ophthalmologic diseases and complications associated with pregnancy and childbirth, determine the tactics of pregnancy and childbirth.

Materials and methods: dates of medical literature in library of Thanscarpathian regional medical informational and analytical center, sources of the Internet.

Results. The problem of the organ of vision occurs quite often. The main tasks for an ophthalmologist who examinates pregnant women include: diagnosis of primary pathology of the organ of vision, especially those that may have a negative prognosis in terms of maintaining vision at self-childbirth, assessment of the condition of the fundus and detection of signs of preeclampsia There are 3 groups of patients taking into account the features of ophthalmic examination of pregnant women: the first one is - physiological pregnancy without pathology of the organ of vision; group II - physiological pregnancy with a pathology of the organ of vision in the anamnesis, such as myopia, peripheral vitriochoreretinal dystrophy,retinal detachment, vitreous, vascular and other; group III is a pathologically progressive pregnancy with a pathology of the organ of vision that has arisen as a result of pregnancy complications such as preeclampsia, anemia, gestational diabetes mellitus and the like. During the pregnancy, a woman should be examinate two times with an ophthalmologist: 1st - in the first trimestr of pregnancy - 1214 weeks; 2 nd - in the third trimester - 30-32 weeks. The third examination is not compulsory for all pregnant women, but those who have a pathological pregnancy. The examination should be performed under conditions of maximal medicated mydriasis, which allows to visualize the peripheral parts of the fundus and to eliminate the presence of dystrophic changes. Monitoring of pregnant women with myopic refraction is very important. The problem of myopia is relevant because of the fact that the presence of high degrees of myopia leads to questions about childbirth tactics. Some authors claim that not the degree of myopic refraction, but the presence of potentially dangerous forms of peripheral vitrechoreoretinal dystrophy determines the risk of rheumatogenic retinal detachment during pregnancy and childbirth. Laser coagulation of the retina allows to minimize the risk of retinal detachment. That's why, in the detection of peripheral vitrechorioretinal dystrophy in pregnant women, it is necessary to do preventive laser coagulation of the retina. Most authors think that it is possible to allocate absolute and relative indications to Caesarean section because of pathology of the organ of vision. The problem of choosing the optimal correlation between the risk of loss of vision during physiological childbirth and the possible development of intra- or postoperative complications due to cesarean section is actual.

Conclusions. Ophthalmologic examination of pregnant women has a number of features. It is necessary to differentiate the physiological manifestations of pregnancy from pathological. Even when an ophthalmologist gives an opinion on the method of woman's childbirth, the gynecologist finally makes the decision in each situation.

Key words: ophthalmologic status, eye diseases, pregnancy, extragenital complications, myopia, vitreochorioretinal dystrophy, preeclampsia. 


\section{Відомості про авторів}

Костур Ксенія Петрівна - ORCID ID 0000-0002-8975-1438, лікар-інтерн за спеціальністю «офтальмологія», ДЗНЗ «Ужгородський національний університет», факультет післядипломної освіти та доуніверситетської підготовки, кафедра хірургічних дисциплін, м. Ужгород, вул. Грибоєдова, 20, 88000.

Фальбуш Ольга Олександрівна - ORCID ID 0000-0002-6003-7601, к.мед.н., доцент кафедри хірургічних дисциплін, факультет післядипломної освіти та доуніверситетської підготовки, ДЗНЗ «Ужгородський національний університет», м. Ужгород, вул. Грибоєдова, 20, 88000.

Корчинська Оксана Олександрівна - ORCID ID 0000-0001-7265-4829, д.мед.н, професор кафедри акушерства та гінекології, медичний факультет, ДВНЗ «Ужгородський національний університет», м. Ужгород, вул. Грибоєдова, 20Б, 88000 . 